\title{
薬局薬剤師における薬学的疑義照会の意識調査
}

\author{
鹿村恵明, ${ }^{*, a, b}$ 高橋淳一, ${ }^{b}$ 大山明子, ${ }^{a}$ 根岸健一, ${ }^{a}$ \\ 伊集院一成, ${ }^{a}$ 上村直樹, ${ }^{a}$ 青山隆夫 ${ }^{a}$
}

\section{A Survey on the Awareness of Community Pharmacists about Raising Pharmaceutical Questions regarding Prescriptions Issued by Physicians}

\author{
Yoshiaki ShiKamura, ${ }^{*, a, b}$ Junichi TAKahashi, ${ }^{b}$ Akiko Oyama, ${ }^{a}$ Kenichi Negishi, ${ }^{a}$ \\ Kazushige IJYUIN, ${ }^{a}$ Naoki KAMIMURA, ${ }^{a}$ and Takao AOYAMA ${ }^{a}$ \\ ${ }^{a}$ Faculty of Pharmaceutical Sciences, Tokyo University of Science, 2641 Yamazaki, Noda, Chiba 278-8510, \\ Japan, and ${ }^{b}$ Emuzu Pharmacy, 829-20 Motogakucho, Ashikaga, Tochigi 326-0058, Japan
}

(Received May 12, 2011; Accepted June 30, 2011; Published online July 13, 2011)

\begin{abstract}
Community pharmacists can provide effective pharmaceutical care by questioning the physicians about their prescriptions. The regulatory authority (Ministry of Health, Labour and Welfare or the like) has been issuing instructions/advice to health insurance-covered pharmacies about the nature of questions to be asked to physicians under the national health insurance system. However, this practice has been facing similar kind of problems almost every year. To identify the reasons for repetition of the problems and facilitate proper application of drug therapy at hospitals, we recently examined the nature of questions asked to physicians by conducting a survey of 165 health insurance-covered pharmacies belonging to 8 district branches of the Japan Pharmaceutical Association. When the pharmacists were asked to express their view whether each of the 18 sample questions included in the past surveys was actually necessary, the most frequent answer from the respondents $(n=1980)$ was "neutral" (42.9\%), followed by "unnecessary" (29.0\%) and "necessary" (26.6\%). Further, $55.5 \%$ respondents answered that it is necessary to refer to publications of the concerned fields (guidelines, etc.) when questioning the prescriptions. However, the responses about the possible reasons for judging the necessity of the questions suggested that sometimes the pharmacists failed to understand the details of such publications. The results from this study suggest that a high percentage of community pharmacists believed that there was little need to ask questions about prescriptions if the suggestions made by the regulatory authority about the relevant questions were taken into account. Further, our study findings suggested that pharmacists working at clinics cannot present a clear-cut rationale for their judgment about the necessity of asking questions about prescriptions under the current circumstances where sufficient information collection and the evaluation of need for asking questions about prescriptions are not possible.
\end{abstract}

Key words_ _ inquiry about prescription; pharmaceutical question; pharmaceutical care; community pharmacist

\section{緒袞}

薬局薬剤師が患者に対し薬学的ケアを行うための 有効な手段の 1 つとして，処方せんの記載内容に関 する医師への疑義照会がある．疑義照会の状況など についてはいくつかの調査結果 1,2$)$ が報告されてい るが，平成 14 年に実施された「医薬分業における 疑義照会の実態に関する研究」では，処方せん枚数 に対する疑義照会率は $2.9 \%$ であり，そのうち 52.9 \%が処方変更につながっているとの報告がある，疑

$a$ 東京理科大学薬学部, ${ }^{b}$ エムズ薬局

*e-mail: shika@sctv.jp
義照会には形式的疑義照会と薬学的疑義照会がある が，鹿村ら $)^{3)}$ にると形式的疑義照会を処方せんの 記載不備と解釈すれば，その多くは処方せん発行側 の問題であり，医療機関側で十分注意していれば本 来は不要な疑義照会である。薬学的疑義照会は薬学 的な判断が必要なものであり, 投与日数制限や休薬 期間が必要な薬剤が不適切に処方されている場合, 服用時点や薬剤の過多・過少投与により薬効に影響 を及ぼすものなどがある．また，相互作用が考えら れる場合や副作用歴からのリスク回避, コンプライ アンスや QOL の改善を伴うもの, 保険上の問題に 関するものなどがある。これらの疑義照会では，薬 
剂師の職能が十分に発揮されていると考えられ，薬 学的ケアによって患者にメリットが得られることが 多い.

一方，厚生労働省や地方厚生局によって，保険薬 局に対する保険指導が実施されている，その目的 は，適正な保険診療・保険調剂を確保し，加えてそ の質を向上させるとなっている，毎年，保険指導な どの指摘事項として，「処方内容に関する薬学的確 認が必要なもの」4-7)が公表されているが，その内容 は毎回同じような事項が指摘されているのが現状で ある。そこで，同様な指摘が繰り返されている理由 を検討し，薬物療法の適正化につなげることを目的 として, 薬局薬剤師に対し薬学的疑義照会に関する 意識調査を行った。

\section{方法}

東京理科大学薬学部の教員を通じて, 社日本薬剂 師会に所属する薬剤師会支部に協力を呼びかけた結 果，足利（杤木県），柏 (千葉県)，板橋（東京都）, 西東京 (東京都)，北多摩（東京都），鎌倉（神奈川 県)，茅ケ崎・寒川（神奈川県），児島（岡山県）の 8 地区の薬剂師会支部において調查協力の賛同が得 られた。

調査期間は 2009 年 8 月末から 9 月にかけての約 1 カ月間とした。回答者は 1 薬局あたり 1 名の薬剤 師で，他の薬剂師と相談することなく調查用紙に記 入するよう依頼した。 また，調査結果にバイアスが 生じることを避けるため, 薬局の抽出は薬剤師会支 部が実施し，解析者には薬局や薬剤師が特定できな いよう配慮した。最終的に対象薬局は 165 軒で，所 在地による内訳は，足利 (20)，柏(25)，板橋 (20), 西東京 (20), 北多摩 (30), 鎌倉 (10), 茅ヶ崎 · 寒川（20），児島（20）であった。

調査票の構成は，本調査の趣旨，回答者の「基本 情報項目」, 調査内容として 18 項目の具体的な疑義 照会事例に対する必要性の判断（「必要である」, 「どちらともいえない,「必要ない」の三者択一回 答と「その理由」の自由記述）についての設問，薬 剤の効果を判定した際に無効と考えられる場合の疑 義照会の必要性（「疑義照会をする」，「どちらとも いえない」,「疑義照会をしない」の三者択一回答), 疑義照会時の参考資料に関する設問，及び薬学的ケ アに貢献したと考える疑義照会実例を 3 例列挙（自
由記述）するとした（Fig. 1)。なお，「基本情報項 目」設問 1-2)に勤務先の所在地を薬剤師会支部で はなく都道府県を記載するとした理由は，保険薬局 に対する保険指導の実施単位が都道府県であるため である。

設問 2 における 18 項目の具体的事例については, 社日本薬剂師会と社日本病院薬剤師会の共催による 平成 16-19 年度の社会保険指導者研修会において, 厚生労働省保険局医療課指導監査室より報告を受け た「共同指導等による主な指摘事項 $\rfloor^{4-7)}$ のうち，処 方内容に関する薬学的確認事項の中から繰り返し指 摘されている事項を選択した。1 18 項目の事例に関 する疑義照会の判断理由についての自由記述回答 は，「疑義照会判断理由の分類基準」（Table 1）に 従って「医薬品添付文書」,「経験」,「エビデンス」 に基づくものと「その他」に分類した.

回答者の「基本情報項目」と 18 項目の疑義照会 事例に対する必要性の判断との関連性について， $\chi^{2}-$ 検定（Spearman，有意水準 $p=0.05 ）$ を行った．統 計解析ソフトには IBM PASW Statistics 18 を用い た.

設問 3-3)における薬学的ケアに貢献したと考え る実例についての自由記述回答は，鹿村ら ${ }^{3)}$ の分類 を基に作成した「薬学的疑義照会内容の分類」 （Table 2）に従って，「日数・回数に関する疑義」, 「用法・用量に関する疑義」,「安全性上の疑義」, 「コンプライアンス・QOL 改善に伴う疑義」及び 「その他」に分類した。なお，記載内容から複数の 項目への該当が考えられる場合は「その他」に分類 し，記載はあるが，内容が疑義照会ではないものは 「無回答」とした。また，「安全性上の疑義」につい ては，その内訳を分類表の細項目に従って分類した。

\section{結果}

薬剂師会支部を通して 165 軒の保険薬局に調査票 を送付し，112 軒から回答を得た（Table 3)。回収 率は 67.9\%であった。

\section{1. 回答者の基本情報項目 本調査の回答者は} 薬局薬剤師を対象としているため, 所属を病院薬剤 師と回答した 1 軒と勤務先の所在地が依頼した支部 と異なる支部を回答した 1 軒について対象から除外 した (Table 3). 回答者の薬剤師としての経験年数 は, 3 年末満 5 人 $(4.5 \%), 3$ 年以上 5 年末満 9 人 

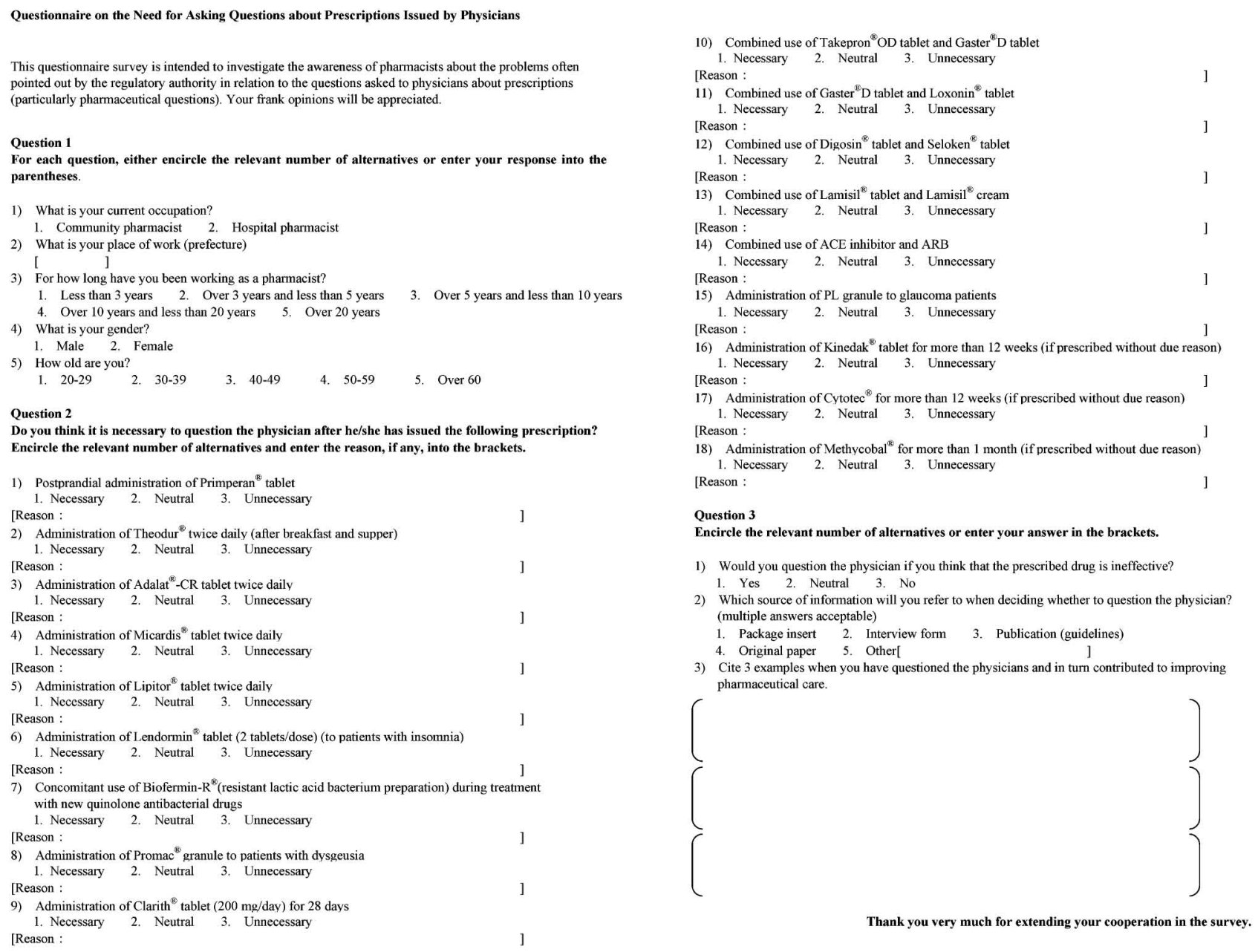

Fig. 1. Questionnaire Used for the Survey on Pharmaceutical Questions about Prescriptions Issued by Physicians

Table 1. Criteria for Classifying the Reasons Based on Which Question Pharmacists Can Ask Physicians about Their Prescriptions

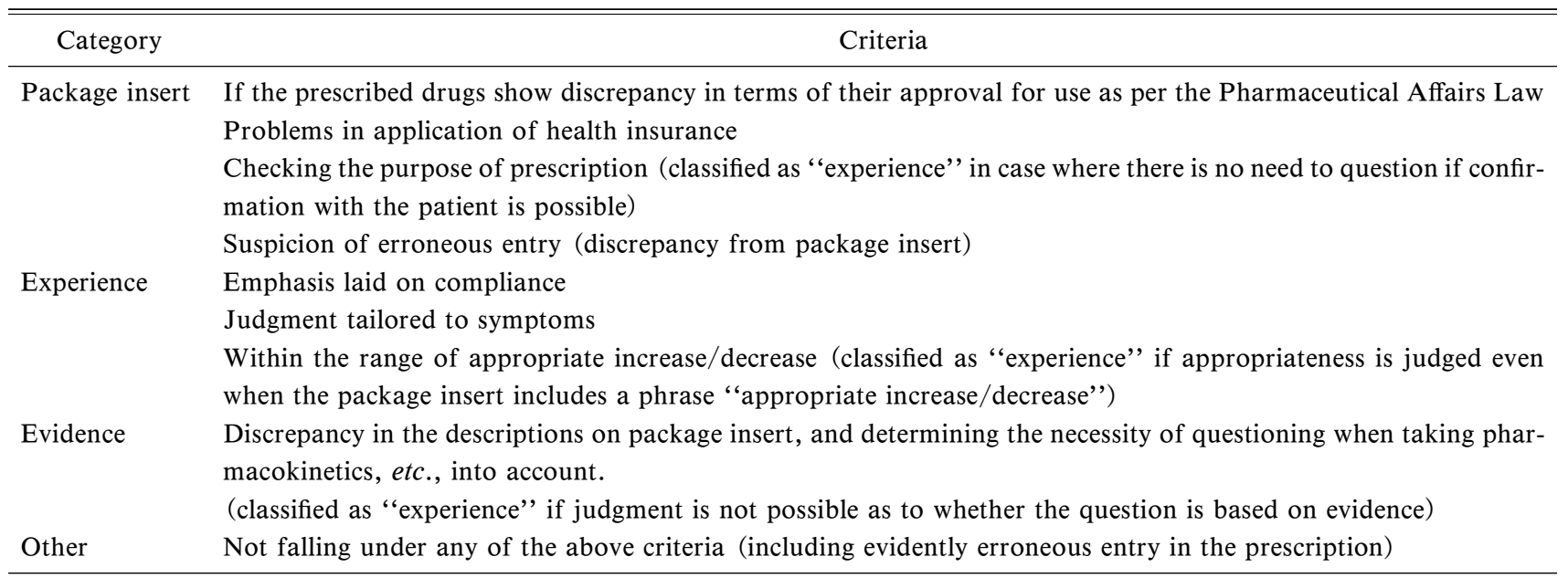


Table 2. Classification of Pharmaceutical Questions on Prescriptions

\begin{tabular}{|c|c|}
\hline Category & Subcategory \\
\hline \multirow{5}{*}{$\begin{array}{l}\text { Question about the number of } \\
\text { days and frequency of dosing }\end{array}$} & Excess/shortage of the number of days \\
\hline & Excess/shortage of frequency of dosing (potion) \\
\hline & Excess/shortage of number of pieces (topical drug, injection, etc.) \\
\hline & Prescription of drugs whose long-term use is prohibited \\
\hline & Appropriateness of dose considering the adjustment of number of days due to residual drug \\
\hline \multirow{7}{*}{$\begin{array}{l}\text { Question about administration } \\
\text { and dosage }\end{array}$} & Question about time of administration \\
\hline & Question about dosing interval \\
\hline & Question about site of use (topical-use drug, etc.) \\
\hline & Excessive dosage (within the range of appropriate increase/decrease in dose) \\
\hline & Shortage of dosage \\
\hline & Question about dose level standards \\
\hline & Question about dosing method (including topical drug/injection) \\
\hline \multirow[t]{12}{*}{ Question about safety } & Prohibited combination \\
\hline & Contraindication \\
\hline & Careful administration \\
\hline & Excessive dosage (beyond the range of appropriate increase/decrease in dose) \\
\hline & History of allergy/adverse reactions \\
\hline & Influence on pregnancy and lactation \\
\hline & $\begin{array}{l}\text { Duplication with other drugs of same indications (duplication with drugs within the same } \\
\text { prescription, in other specialty's prescription, OTC drug, etc.) }\end{array}$ \\
\hline & $\begin{array}{l}\text { Interactions (with drugs within the same prescription, in other specialty's prescription, OTC } \\
\text { drug, etc.) }\end{array}$ \\
\hline & Change in drug (compared with previous prescription, etc.) \\
\hline & Change in dose level (compared with previous prescription, etc.) \\
\hline & Incomplete entry in the prescription (compared with previous prescription, etc.) \\
\hline & Checking the purpose of prescription \\
\hline \multirow{4}{*}{$\begin{array}{l}\text { Question about compliance and } \\
\text { quality of life }\end{array}$} & Appropriateness of single-pack dispensing, tablet crushing, etc. \\
\hline & Change in formulation \\
\hline & Change in dosing method, etc., due to daily habits \\
\hline & Change in prescription based on patient's request \\
\hline Other & Cases other than those listed above \\
\hline
\end{tabular}

Table 3. Number of Pharmacies in Each Block Which Received the Questionnaire and The Response Rate

\begin{tabular}{cccc}
\hline \hline Block & $\begin{array}{c}\text { No. of } \\
\text { pharmacies }\end{array}$ & $\begin{array}{c}\text { Response } \\
\text { (invalid) }\end{array}$ & $\begin{array}{c}\text { Response } \\
\text { rate }\end{array}$ \\
\hline Ashikaga & 20 & 17 & $85.0 \%$ \\
Kashiwa & 25 & 23 & $92.0 \%$ \\
Itabashi & 20 & $15(1)$ & $75.0 \%$ \\
Nishi-Tokyo & 20 & 3 & $15.0 \%$ \\
Kitatama & 30 & $20(1)$ & $66.7 \%$ \\
Kamakura & 10 & 7 & $70.0 \%$ \\
Chigasaki/Samukawa & 20 & 15 & $75.0 \%$ \\
Kojima & 20 & 12 & $60.0 \%$ \\
\hline Total & 165 & $112(2)$ & $\begin{array}{c}67.9 \% \\
(\text { mean })\end{array}$ \\
\hline
\end{tabular}

$(17.3 \%) ， 20$ 歳代 $(8.2 \%) ， 60$ 歳以上（7.3\%）の 順であった。

2. 18 項目の疑義照会事例に対する必要性の判 断 18 項目の疑義照会事例に対する必要性の判 断を総回答数 $(n=1980)$ に対する割合で示すと, 「どちらともいえない」が $42.9 \%$ と最も多く, 「必 要である」が $26.6 \%$ ，「必要ない」が $29.0 \%$ ，無回 答が $1.5 \%$ であた。事例を「必要である」と回答 した割合が多い順に並べると「タケプロン ${ }^{\circledR} \mathrm{OD}$ 錠 とガスター ${ }^{\circledR} \mathrm{D}$ 錠の併用」が最も多く $80.0 \%$, 次に 「緑内障患者に対し，PL 顆粒を投与」 $45.5 \%$ 「リ ピトール ${ }^{\circledR}$ 錠の 1 日 2 回投与」 $44.5 \%$,「ミカルディ ス ${ }^{\circledR}$ 錠の 1 日 2 回投与」と「アダラート ${ }^{\circledR} \mathrm{CR}$ 錠の 1 日 2 回投与」がともに $37.3 \%$ の順であった（Fig. 


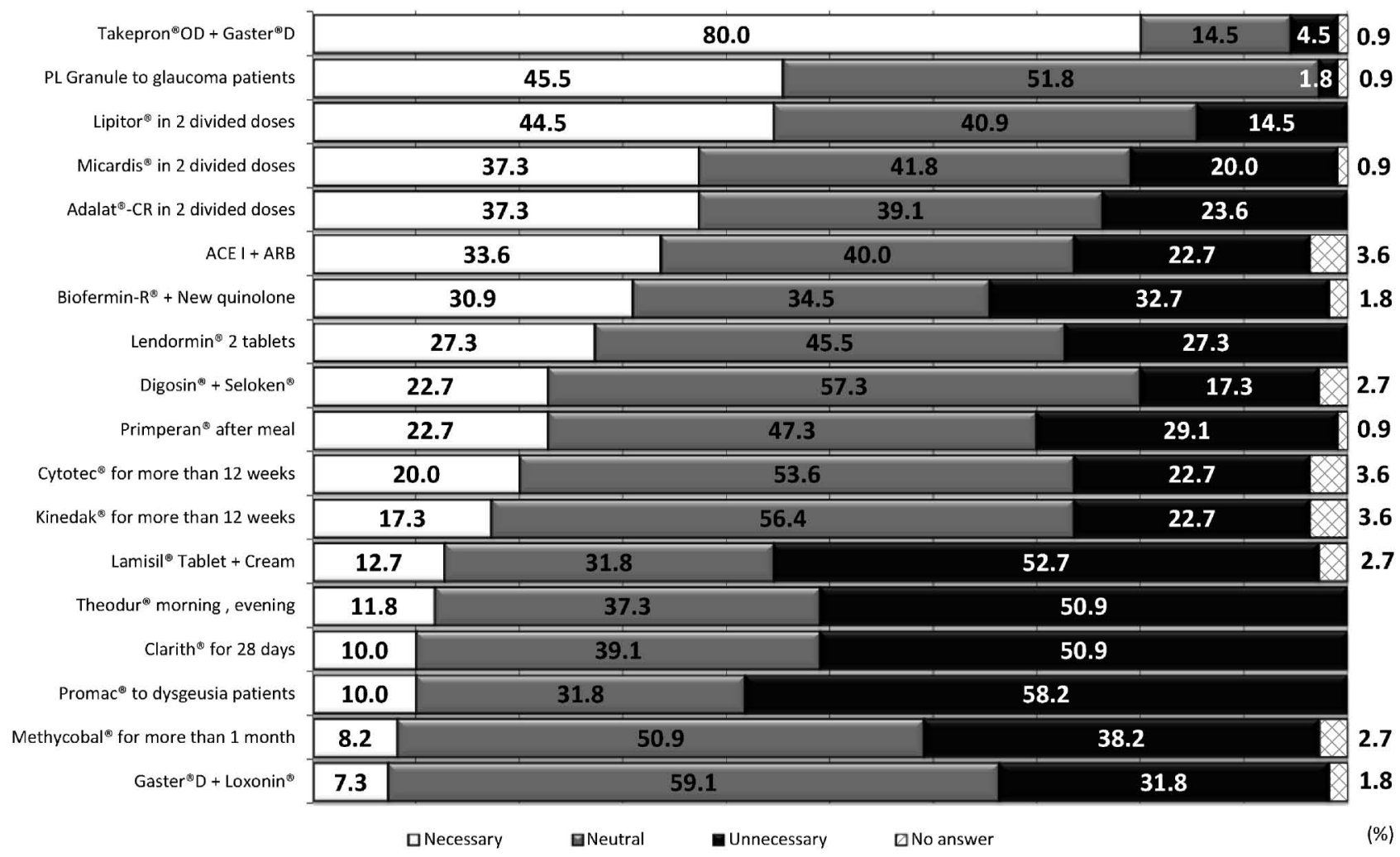

Fig. 2. Percentage of Respondents Judging Each of the 18 Questions as "Necessary" $(n=110)$ among the Total Respondents

2).また，「必要がない」と回答した割合が多い順 に並べると「プロマック顆粒を味覚障害の患者に 投与」が最も多く $58.2 \%$ ，次に「ラミシール錠と ラミシール ${ }^{\circledR}$ クームの併用」52.7\%，「クラリス ${ }^{\circledR}$ 錠 $200 \mathrm{mg}$ /日の 28 日投与」と「テオドール錠の 1 日 2 回朝夕食後投与」がともに $50.9 \%$ の順であつ た (Fig. 3).

3. 薬が無効と考えられる場合の疑義照会の有無 薬の効果判定をした際に無効と考えられる場合の 疑義照会の有無については，「どちらともいえない」 が 63.6\% と最も多く，以下「疑義照会する」18.2\%， 「疑義照会しない」 $13.6 \%$ 「「回答なし」4.5\%の順 であった $(n=110)$.

4. 疑義照会時の参考資料設問 3-2)におけ る疑義照会に用いた参考資料についての設問（複数 回答可）は，「医薬品添付文書」を参考にするが $97.3 \%$ ，「インタビューフォーム」が $41.8 \%$ ，「専門 書（ガイドライン）」が $55.5 \%$ ，「原著論文」が 6.4 \%,「その他」 $29.1 \%$ \%あった $(n=110)$.「その他」 の中には，「インターネット」と回答した事例があ つたが，インターネットからどのような情報を検索 して参考にしているかについては，記載されていな
かつた。

5. 「基本情報項目」と 18 項目の疑義照会事例に 対する必要性の判断の関連性「勤務先の所在地 (都道府県)」による回答に差が認められたのは, 「プリンペラン錠の食後投与」 $(p=0.00)$,「テオドー

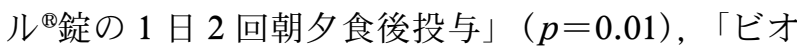
フェルミン $\mathrm{R}^{\circledR}$ (耐性乳酸菌製剂) をニューキノロ

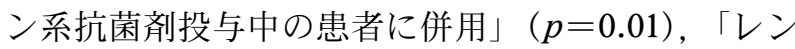
ドルミン 錠の 1 回 2 錠投与 (不眠症患者に対して)」 $(p=0.02)$ の 4 項目であった.「プリンペラン ${ }^{\circledR}$ 錠の 食後投与」に関しては，栃木県では「必要である」 と回答した者が $70.6 \%$ あったのに対し，東京都 では皆無であった。また，「テオドール錠の 1 日 2 回朝夕食後投与」についても杤木県では「必要であ る」が 52.9\%であつたが，千葉県 $8.7 \%$ ，東京都 $5.6 \%$ であ，神奈川県，岡山県では 1 例もなかつ た. 服用時点が医薬品添付文書に記載された薬事法 の承認内容と異なる事例に関しては，他地域と比較 すると栃木県では疑義照会が必要であると考えてい る割合が多かつた。さらに栃木県の回答の中で疑義 照会が必要であるとしたその理由について，「プリ ンペラン®錠の食後投与」で 12 例中 8 例, 「テオドー 


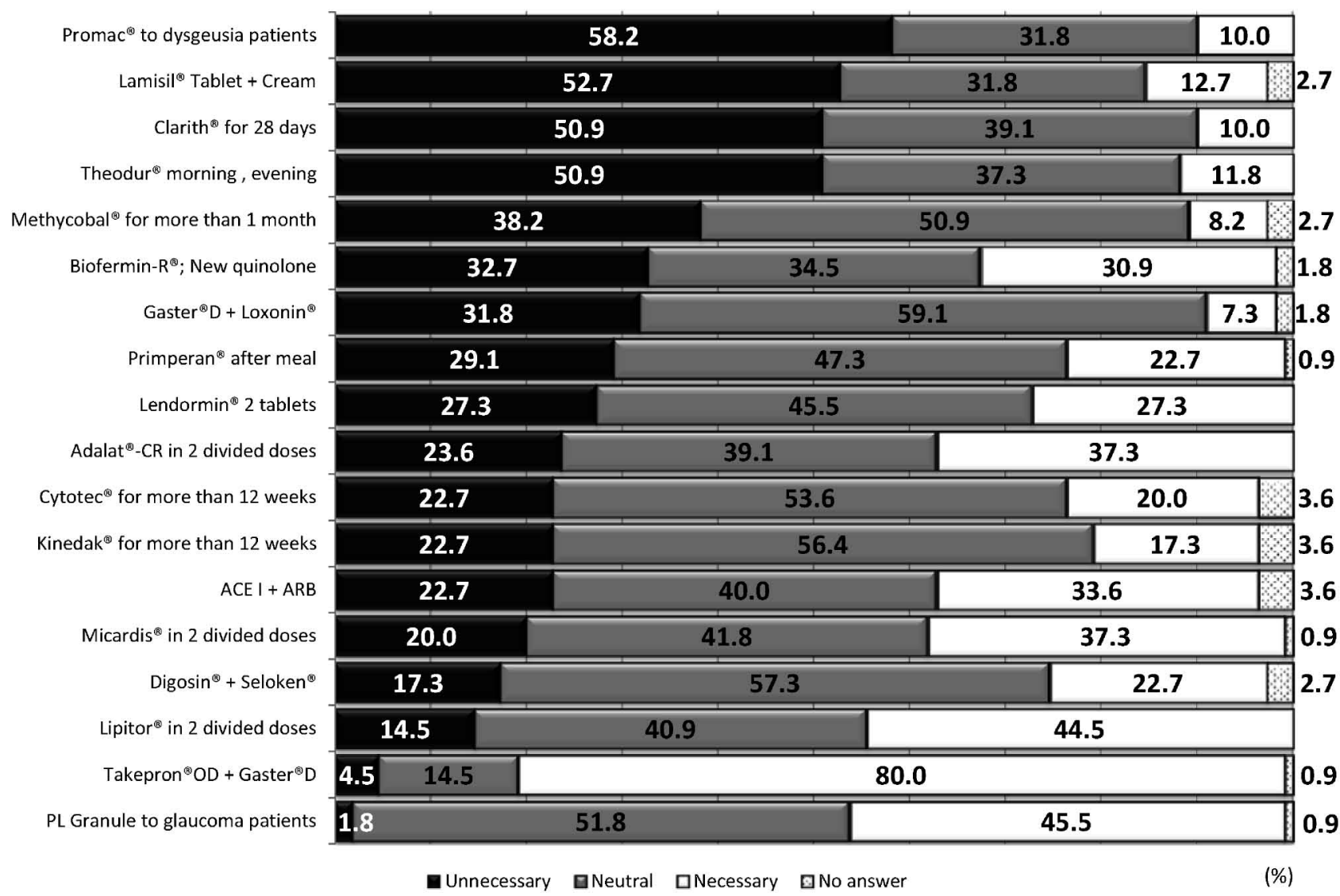

Fig. 3. Percentage of Respondents Judging Each of the 18 Questions as "Unnecessary" ( $n=110)$ among the Total Respondents

ル®錠の 1 日 2 回朝夕食後投与」で 9 例中 7 例が添 付文書の記載と違うなど，薬事法の承認内容と異な ることを理由に挙げていた。

「薬剤師としての実務経験年数」では，「ガス夕 一 ${ }^{\circledR} \mathrm{D}$ 錠とロキソニン ${ }^{\circledR}$ 錠の併用」のみに有意差が あつたが $(p=0.04)$ ，疑義照会が必要であると回答 した者が 10 年末満では 1 例もなかつたが，10 年以 上 20 年未満では $10 \%, 20$ 年以上では $13.3 \%$ が必 要であると回答しており，実務経験が長い方が疑義 照会の必要性を感じていた。

「性別」では「プリンペラン央錠の食後投与」（ $p$

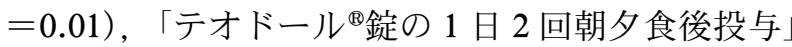
$(p=0.03)$ の 2 項目で有意差があり,「年齢」で有 意差があつたのは「アダラート ${ }^{\circledR} \mathrm{CR}$ 錠の 1 日 2 回 投与」（ $p=0.02 ）$ のみであった.「アダラート ${ }^{\circledR} \mathrm{CR}$ 錠の 1 日 2 回投与」に関しては，「必要である」と 回答した割合が 20 歳代 $66.7 \% ， 30$ 歳代と 40 歳代 では各 $40.5 \%, 50$ 歳代では $26.3 \%, 60$ 歳以上では $0.0 \%$ ありり，年齢が高いほど疑義照会の必要性を 感じていなかった。
6. 設問 2 における疑義照会の判断理由 設問 2 における疑義照会の判断理由についての自由記述 回答を「疑義照会判断理由の分類基準」（Table 1) に従って分類した結果（Figs. 4 and 5）では，疑義 照会を行う必要があると判断した場合では医薬品添 付文書の記載を根拠としたものが多く，エビデンス に基づいたものは少なかつた。エビデンスに関する 記載があつたものは, 「アダラート ${ }^{\circledR} \mathrm{CR}$ 錠の 1 日 2 回投与」，「ミカルディス ${ }^{\circledR}$ 錠の 1 日 2 回投与」,「リ ピトール 錠の 1 日 2 回投与」,「ビオフェルミン $\mathrm{R}^{\circledR}$ をニーキノロン系抗菌剂投与中の患者に併 用」,「ACE 阻害薬とARB の併用」の 5 項目であ り，他の 13 項目では全くなかった。また，疑義照 会を行う必要がないと判断した場合では経験に基づ くものが多く（15 項目），エビデンスに基づくもの も 12 項目で記載があった。「夕ケプロン ${ }^{\circledR} \mathrm{OD}$ 錠と ガスター ${ }^{\mathbb{D}} \mathrm{D}$ 錠の併用」については，「医薬品添付 文書」と「経験」に分類されるものはなく，理由の 記述があった $(20 \%)$ ものは，すべて「エビデンス」 に基づく内容であった. 


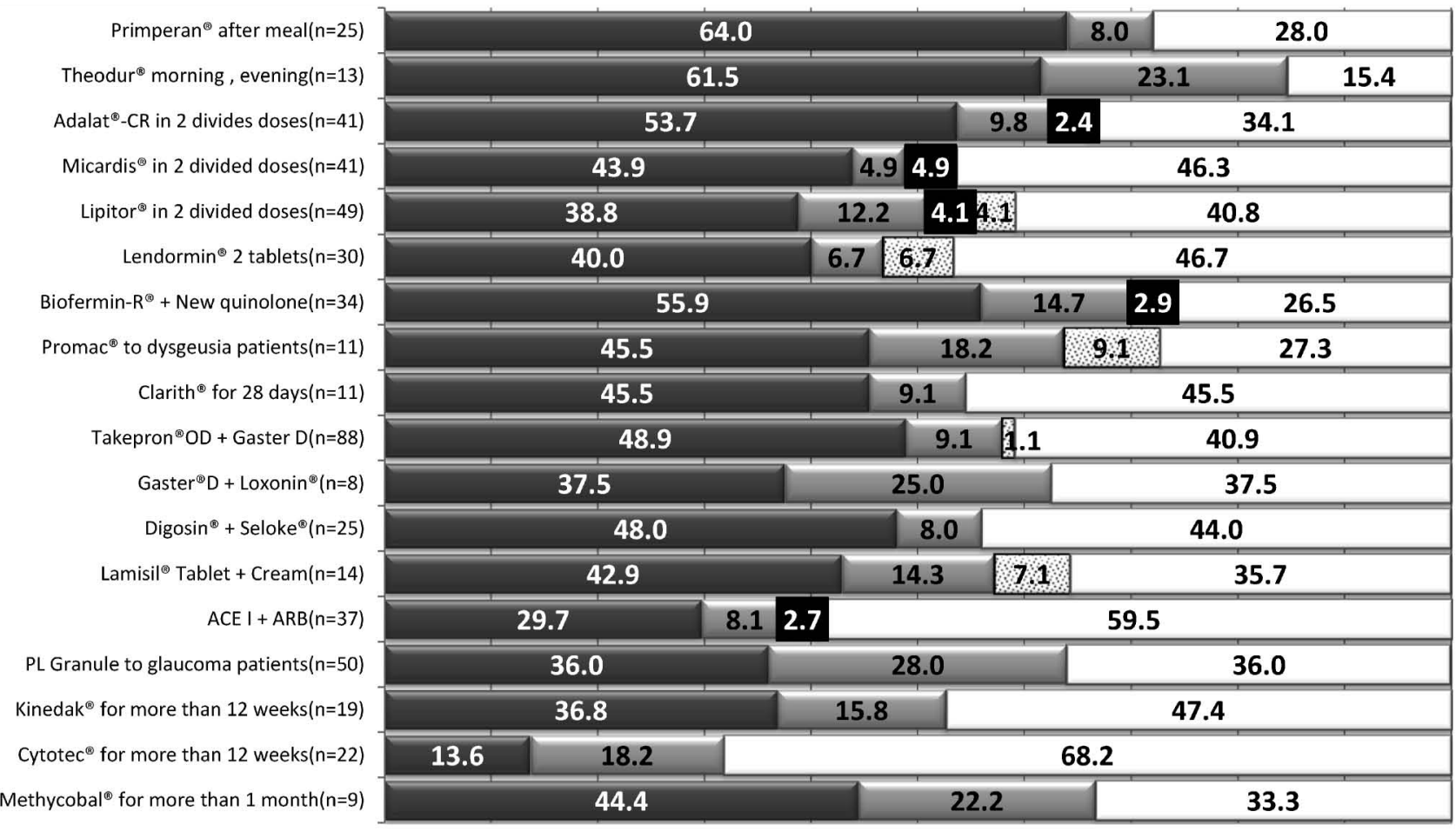

घPackage insert $\square$ Experience $\mathbf{E}$ Evidence $\mathbf{0}$ Other $\square$ No answer

Fig. 4. Percentage of Respondents $(n=110)$ among the Total Respondents Who Answered That the Judgment Was "Necessary"

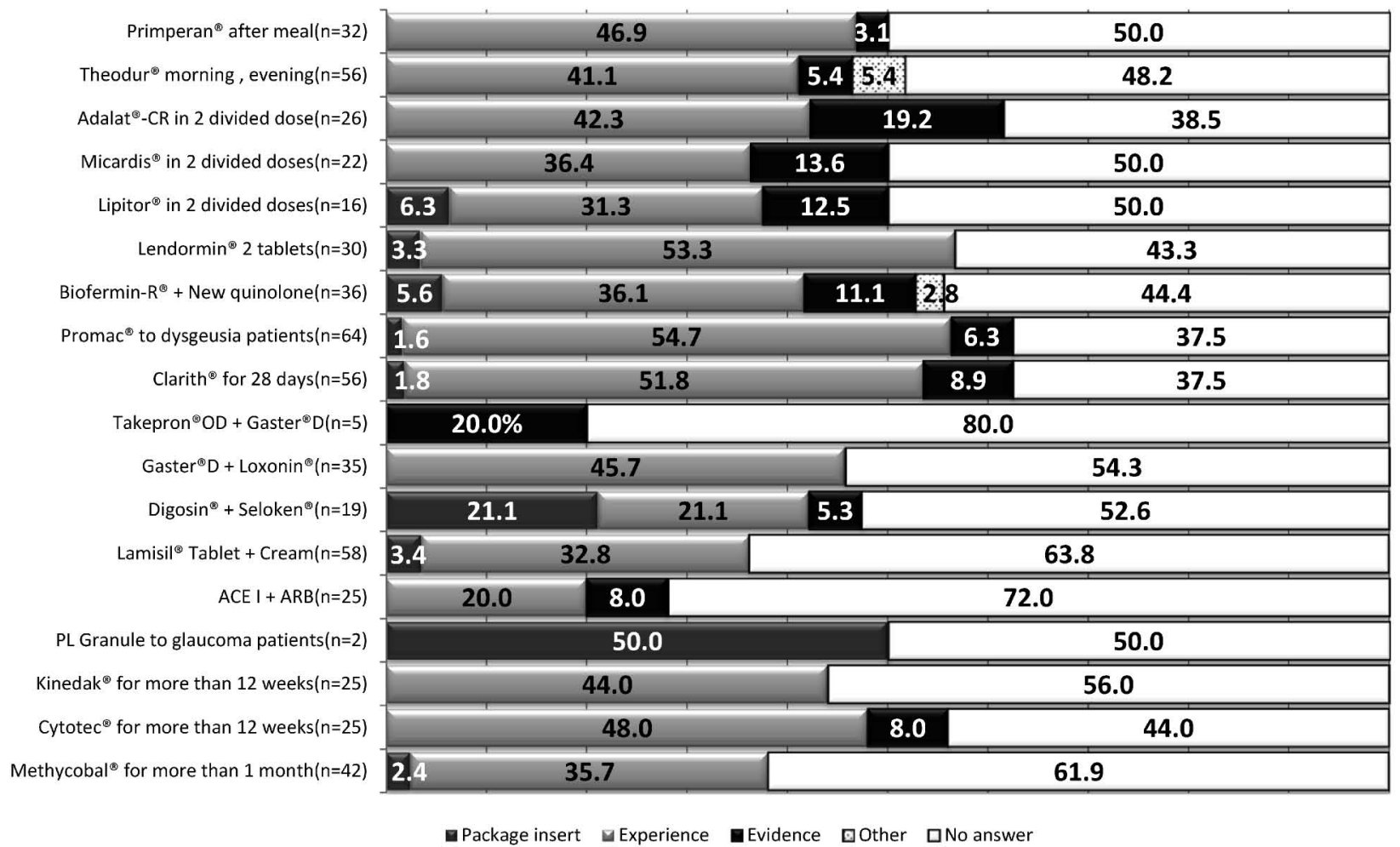

Fig. 5. Percentage of Respondents $(n=110)$ among the Total Respondents Who Answered That the Judgment Was "Unnecessary" 
7. 薬学的ケアに貢献したと考える実例 設問 3-3)における薬学的ケアに貢献したと考える実例に ついての自由記述回答を「薬学的疑義照会内容の分 類」（Table 2）に従って，「日数・回数に関する疑 義」，「用法・用量に関する疑義」，「安全性上の疑 義」，「コンプライアンス・QOL 改善に伴う疑義」, 「その他」に分類した結果を Fig. 6 に示す。安全性 上の疑義に関する実例が $48.8 \%$ と最も多かった が，実例の記入が空欄となっていたものが $37.9 \%$ あった。「安全性上の疑義」161 例について，その 内訳を分類表（Table 2) の細項目に従って分類し た結果では，「アレルギー・副作用歴」 $24 \%$ ，「投与 禁忌」 $18 \%$ ，「相互作用」 $16 \% ， 「$ 同種同効薬の重複」

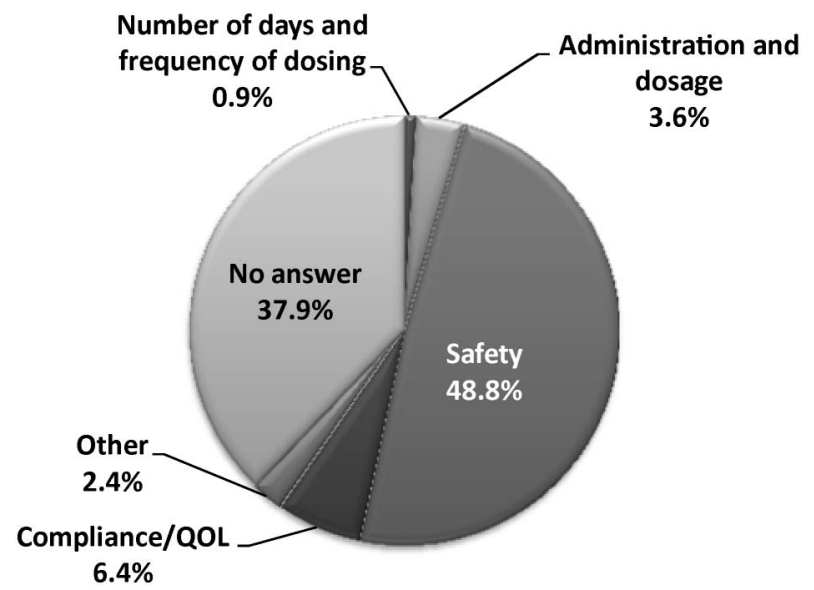

Fig. 6. Classification of the Questions That Contributed to Improving Pharmaceutical Care $(n=330)$

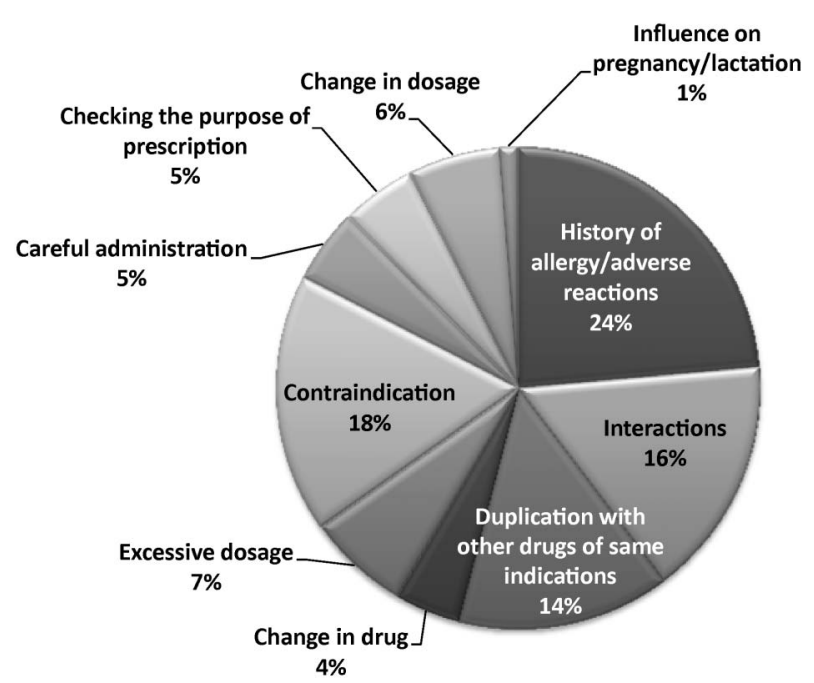

Fig. 7. Sub-classification of the Questions for Reasons of Safety That Contributed to Improving Pharmaceutical Care $(n=161)$
14\%の順で多かった（Fig. 7).

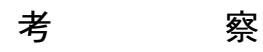

調査票中の設問 3-1）「薬の効果判定をした際に 無効と考えられる場合の疑義照会の有無」について は，「疑義照会する」との回答が $18.2 \%$ であり，こ の割合は設問 2 のキネダック錠とサイトテック®錠 が 12 週を超えて漫然と処方されている場合におけ る疑義照会が「必要である」と回答した割合に近い が，「メチコバール錠の月余にわたる投与」の疑義 照会の必要性に関しては「必要である」と回答した 割合が低く $(8.2 \%)$, 薬局薬剤師にとって，患者か メチコバール錠を 1 カ月程度服用した時点では, 効果の有無を確認できるまでには至らないものと思 われる。また，設問 3-1)では「どちらともいえな い」との回答が最も多く，設問 2 の 16)-18)におけ る「漫然と投与されている場合」の「その理由」に ついても，漫然と処方されているかどうかの判断が 困難であるとの記載内容が多く見受けられたことか ら，このようなケースにおいて薬局薬剤師が薬の効 果判定をすることや疑義照会の必要性を判断するこ とは困難であると考えられる．

保険指導の実施単位が都道府県であるため, 地域 差の有無を確認したが，「基本情報項目」と 18 項目 の疑義照会事例に対する必要性の判断の関連性につ いては，有意差があった項目はいずれも 1-4 項目で あり，回答者の属性による回答内容の差は，少なか ったと言える。しかし，服用時点が添付文書に記載 された薬事法の承認内容と異なる事例に関しては, 他地域と比較すると栃木県で疑義照会が必要である と回答している割合が高く，その理由について，添 付文書の記載と違うことなどを挙げていたことを考 慮すると，栃木県の調查は足利支部のみのデータで あるため，断定はできないものの，栃木県の薬局薬 剂師においては，服用時点が添付文書の記載と異な つている場合は，他地域の薬剂師よりも積極的に疑 義照会を行っている可能性がある.

回答者の「年齢」で有意差があった「アダラー 卜 ${ }^{\circledR} \mathrm{CR}$ 錠の 1 日 2 回投与」に関しては，年齢が高 いほど疑義照会の必要性を感じておらず，この項目 に関する疑義照会の必要がないと判断した理由 （Fig. 5）においても，「経験」の割合が最も高く, 薬剂師としての経験を重ねていくほど疑義照会が不 
要と判断する傾向がある．また，疑義照会の必要が ないと判断した理由（Fig. 5）の中で，「エビデン ス」の割合も他の項目と比較して高い割合であった ため, 「アダラート ${ }^{\circledR} \mathrm{CR}$ 錠の 1 日 2 回投与」につい ては，薬事法の承認内容と異なる服用時点であって も，薬剂師が臨床的に治療効果を感じていると思わ れる場合には疑義照会を積極的に行わず，患者の経 過観察を行っているものと考えられる.

疑義照会を行う際の参考資料の設問では，専門書 （ガイドライン）を参考にしていると回答した割合 は半数を超えていた。一方で，高血圧治療ガイドラ イン 2009（JSH2009）において，「降圧薬は 1 日 1 回投与を原則とするが，24 時間にわたつて降圧す ることがより重要であり，1 日 2 回の分割投与が好

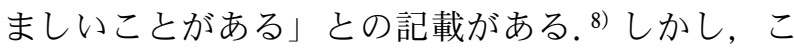
のガイドラインの記載を根拠として疑義照会の必要 性を判断していると思われる自由回答欄への記載は 「アダラート ${ }^{\circledR} \mathrm{CR}$ 錠の 1 日 2 回投与」で 2 例, 「ミ カルディス錠の 1 日 2 回投与」で 1 例のみであつ た。また，疑義照会の必要性の判断（Fig. 2) にお いて，「タケプロン ${ }^{\circledR} \mathrm{OD}$ 錠とガスター ${ }^{\circledR} \mathrm{D}$ 錠の併用」 に関して「必要である」と回答した割合が最も多か つたが，重症の逆流性食道炎では，Proton Pump Inhibitor（PPI）投与中でも，夜間に胃内 $\mathrm{pH}$ が 4 未満となる時間が 1 時間以上連続して認められる現 象 (Nocturnal Gastric Acid Breakthrough: NAB) を起こすことがある．NAB については，PPI の増 量や夜間服用では効果が十分ではなく，PPI 投与に 加えて就寝前に $\mathrm{H}_{2}$-blocker を併用した場合，NAB の発現を抑制できるという報告がある。臨床的に PPI と $\mathrm{H}_{2}$-blocker を併用する事例があることを知 つていると思われる記述はあったが，自由記述の中 でNAB について記載されたと判断できるものは 1 例のみであることから判断すると, 薬局薬剤師が専 門書（ガイドライン）を参考にしても，詳細な部分 までは理解していない可能性がある。近年,

Evidence-based medicine (EBM) が重要視されつつ あり，原著論文を読み，論文を批判的に吟味する能 力も薬剤師に求められる。そのためには，疑義照会 の際に原著論文を参考にしている割合が 6.4\%では 少なく (Fig. 7), 薬物療法に関する本質的な疑義 照会はできていないと考える。

薬学的ケアに貢献したと思われる実例では，安全
性上の疑義に関する事例が半数近くを占め（Fig. 6)，安全性上の疑義をその内容によって分類した結 果では（Fig. 7)，「アレルギー・副作用歴」，「投与 禁忌」,「相互作用」, 「同種同効薬の重複」の順で多 かつたが，松原ら ${ }^{9)}$ の報告にあるように最近ではこ のような疑義の確認の大部分は電子薬歴などによっ て可能であり, 将来的には薬剂師に頼らなくても実 施可能となると思われる。しかし，同じように「ア レルギー・副作用歴」に関して回答欄に記述された 内容で，カルシウム拮抗薬による歯肉肥厚やアンジ オテンシン変換酵素阻害薬による空咳などの副作用 に関するその患者固有の情報収集が必要な疑義に関 しては，患者とのコミュニケーションが不可欠であ り，コンピュータ上の情報からは判断できない。今 後, 薬剂師の職能を発揮するためには患者固有の情 報を踏まえて薬学的管理をすることが重要であると 考える.

本研究によって，厚生労働省が報告している保険 指導などにおける主な指摘事項の中で，処方内容に 関する薬学的確認は，現場の薬局薬剤師は必要性が 高いとは思っていないことが示唆された。その原因 の 1 つは，現場で行われている医療には最低限の医 療を行うために，診療ガイドラインを基に「医療の 標準化」を行うという考え方があり，ガイドライン には薬事法の承認内容以外の学会レベルで認められ ている適応法も採用されているためであると考え る.また一方で，「医療の個別化」という考えでは， 診療ガイドラインにとらわれず，その患者にとって 最適の医療をすることを目指しており，このような 現場の医療の流れの中で, 薬局薬剂師は保険診療上 の適応の問題点だけを理由として医師に疑義照会し てよいのか判断に迷い，躊躇していることがあるの ではないだろうか.

一方，現場の薬剂師がこれらの指摘事項に関する 疑義照会の必要性の判断について，妥当な情報の収 集・評価ができていないため，根拠を示せないこと がわかつた。薬剤師法第 24 条では，「薬剤師は，処 方せん中に疑わしい点があるときは，その処方せん を交付した医師，歯科医師又は獣医師に問い合わせ て，その疑わしい点を確かめた後でなければ，これ によって調剤してはならない」と規定されており， 疑義照会をせずに調剤を行うということは，薬剤師 としての義務と責任を果たしていないと言える、今 
後は薬剂師の個人的な経験上の判断だけではなく, 能動的に情報収集を行い，その情報を批判的に吟味 した上で疑義照会の必要性を判断したという根拠を 示していくことが求められる.

薬局薬剂師には, 薬物療法の適正化に貢献するこ とが求められており，医療関連情報や患者からの情 報を十分に収集し，得られた情報を基に薬学的疑義 照会を積極的に行い，その患者固有の問題点を解決 することが患者中心の薬学的ケアにつながるものと 考える。

謝辞＼cjkstart薬局業務の忙しい中, 本調査にご協力し て頂いた薬剤師会支部の皆様，回答して下さった薬 剤師の方々に深く感謝申し上げます。

\section{REFERENCES}

1) Nakamura T., Kamei M., Suganuma T., $J$. Jpn. Pharm. Assoc., 51, 1860-1877 (2000).
2) Nakamura T., J. Jpn. Pharm. Assoc., 54, 743 -766 (2002).

3) Shikamura Y., Takahashi J., Shimizu K., J. Jpn. Pharm. Assoc., 58, 195-200 (2006) .

4) Japan Pharmaceutical Association, J. Jpn. Pharm. Assoc., 57, 593-599 (2005).

5) Japan Pharmaceutical Association, J. Jpn. Pharm. Assoc., 58, 75-81 (2006).

6) Japan Pharmaceutical Association, J. Jpn. Pharm. Assoc., 59, 153-158 (2007).

7) Japan Pharmaceutical Association, J. Jpn. Pharm. Assoc., 60, 583-587 (2008).

8) The Japanese Society of Hypertension, "Guideline for Management of Hypertension, JSH2009," Life Science Publishing Co., Ltd., Tokyo, 2009, pp. 37-45.

9) Matsubara H., Tomita M., Yamamoto T., Moriwake M., Sato H., Toda T., Inotsume N., Hayakawa T., J. Jpn. Pharm. Assoc., 61, 1013-1015 (2009). 